\title{
An Empirical Perspective on the Relationship Between Innovation Performance and Sustainable Development
}

\author{
Sema YiĞì ${ }^{1}$
}

\begin{abstract}
In 2015, almost all member states of the United Nations adopted seventeen Sustainable Development Goals (SDGs), which provide specific objectives and timelines to promote inclusive prosperity. Innovation is crucial for achieving sustainable development. Innovation itself is one of the SDGs (Goal 9) and also a means for achieving the others.

It is aimed to reveal the multidimensional relationship of innovation with the pillars of sustainable development in this study. The dataset of the study consists of 35 OECD member countries and statistics of these countries between 20072019 years. Global innovation scores of countries were used for innovation. Human Development Index was used for the social dimension, $\mathrm{CO}_{2}$ emission values were used for the environmental dimension and GDP per capita was used for the economic dimension. The balanced panel was resolved through Eviews and STATA software packages programs.

According to the results of the analysis, innovation has a positive and significant relationship with the social and economic pillars of sustainable development. It also has a significant but negative relationship with $\mathrm{CO}_{2}$ emission, which negative relationship is a positive situation for the environment. Therefore, the main result of the study is innovation has a positive effect on sustainable development. According to the causality test results, it was determined that there are both short and long-run relationships between the three dimensions of innovation and sustainable development.
\end{abstract}

Keywords: Innovation performance, Sustainable development, Three pillars of sustainable development, OECD countries, Panel data analyses, Causality test

\section{INTRODUCTION}

Environmental, social and economic trends, such as population growth, resource depletion, and growth in an imbalance in income distribution, are among the biggest challenges facing today's society. Sustainable development has received increasing attention among both academicians and policymakers driven by these challenges. Sustainable development is a concept as the result of increased awareness of global links between increased environmental problems and of concerns about the quality of life for today and future (Smedt, 2006, p. 2).

The view that innovation is a key driving force for sustainable development is widely accepted among researchers, industry professionals, and policy makers (Silvestre \& Tî̀rcă, 2019, p. 325). Innovation as a process of creating novelty and more importantly, spreading it, can be considered an integral part of the transformation towards sustainable development (Praetorius et al., 2009, p. 4).

Also, the 2030 Sustainable Development Agenda sets out an extensive and ambitious agenda for global action on sustainable development. The scale and focus of SDGs require innovation in development and innovation for development. Innovation involves new or improved technological products and processes, as well as new forms of social implementation and organization, is not only a focus of Goal 9 (industry, innovation, and infrastructure) also it enables reaching most of (if not all) goals (UNCTAD, 2017, p. 1).

In the 2030 Agenda, Science, technology, and innovation have been recognized as one of the main driving forces behind productivity gains and long-term key leverage for economic growth and prosperity, and are vital for environmental sustainability (Giovannini et al., 2015, p. 12). In a broader sense, implementation 
of SDGs will require an agile, flexible and integrated global innovation system, consciously connect regions around the world, link actors in research and society, and facilitate joint production and transfer of locally relevant information and technology (Stafford-Smith et al., 2017, p. 913).

In this study, it is aimed to empirically test the argument that innovation is a driving force of sustainable development. To fully reveal the relationships, the relationship between the three dimensions of sustainable development and innovation performance has been examined, in accordance with the multi-dimensional structure of sustainability. Firstly, the concept of sustainable development, which is the subject of the study, has been defined. Afterward, the relationship between sustainable development and innovation has been examined for building background to test the main assumption of the study.

\section{SUSTAINABLE DEVELOPMENT}

Although the modern sustainability or environmental movement can be traced from Henry David Thoreau (1854) to Rachel Carson (1962), it did not come to the fore until the Brundtland Report published in the 1980s (Garren \& Brinkmann, 2018, p. 6-10).

The aim of the Brundtland Commission, also known as the World Commission on Environment and Development (WCED), is to guide the world nations towards sustainable development and has been active from 1984 to 1987 . They published the results of their work in the 1987 Brundtland report. This report has made it possible for sustainable development to become an important concept in the glossary of politicians, practitioners, and planners.

Sustainable development can be explained in several ways, but the most widely accepted and quoted definition was expressed by the Brundtland Commission in (1987):

"Sustainable development is development that meets the needs of the present without compromising the ability of future generations to meet their own needs."

According to Munier (2005), this definition consists of three basic components. Development as the first means advancement in economic growth, social progress, and environmental protection. The present as a second element refers to the need to act in the present time with the responsibility of future generations. Lastly, the future refers to the long-term future inhabited by our descendants (Munier, 2005, s. 10-11).

Usually, sustainable development is modeled/operationalized and understood in several so-called "pillars" or "dimensions", commonly as economy, environment, and society/social (Waas, et al., 2011, p. 1650).

\subsection{Pillars of Sustainable Development}

Sustainable development has three main pillars: economic, environmental, and social. To realize sustainable development, it is necessary to focus on economic, environmental and social sustainability together. These pillars often shown as three overlapping-circles and sometimes shown as literal pillars:
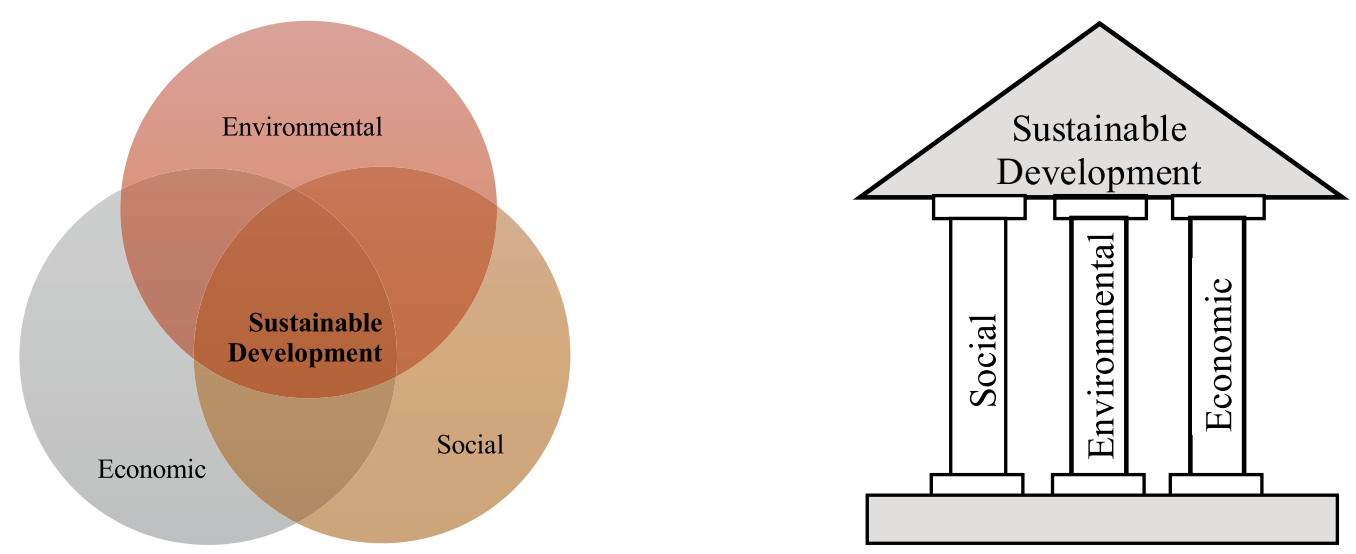

Figure 1: The Three Pillar Model and Literal Pillars Approach of Sustainable Development Source: (Purvis, Mao, \& Robinson, 2019, p. 682). 
According to the Brundtland report, social sustainability is defined as the building of long term, stable and dynamic societies where basic human needs are fulfilled. Social sustainability is partly a sustainable economy and partly a problem of culture and values. Economic sustainability focuses on the importance of healthy economies that provide a high quality of life to its citizens. Besides, economic sustainability often involves identifying alternative economic development paths that provide a safer future without compromising the long-term ecological sustainability of natural systems (Batie, Sedjo, \& Fedkiw, 2008, p. 13). Environmental sustainability defines an existing boundary to meet the current needs of people without sacrificing the quality of the environment or ecosystem so that the needs of future generations can be equally met (Kaswana et al., 2009, p. 493).

\section{THEORETICAL BACKGROUND AND HYPOTHESIS DEVELOPMENT}

Innovation is a desirable phenomenon for both economic and sustainable growth. However, each of these points of view highlights the importance of innovation for many different reasons. If an invention brings success in the market, innovation is considered positive for economic growth. However, from a sustainable development perspective, positive effects are only taken into account in the development of all three dimensions, namely ecological, economic and social innovations (Hauff \& Jörg, 2010, p. 38). Although the relationship between economic development and innovation is frequently the subject of research in the literature, few studies are addressing the relationship between sustainable development and innovation.

Innovation is an ongoing process, and it happens every day and builds a future for the next generations to live. Innovation includes not only new technology, but also new forms of organization, new practices, new dissertations and new ideas about global and local concerns. So innovation is highly intertwined with sustainable development (Praetorius et al., 2009, p. 1).

Santana et al. (2015) have assessed the relationship between sustainable development and investments in technological innovation. They made comparisons for BRICS and G7 countries. Their results demonstrate that technological innovation has a significant impact on all sustainable development pillars for the BRICS countries. However, in G7 countries, technological innovation was found significant only for the social dimension of sustainable development (Santana et al., 2015, p. 425).

Constantinescu and Frone (2014) have shown that technological innovation is crucial for advancing sustainable development. It has an impact on three pillars as economic vitality, environmental sustainability and efforts to promote social progress (Constantinescu \& Frone, 2014). Similarly, Mulder (2007) also mentioned the importance of technological innovation for sustainable development (Mulder, 2007, p. 253).

In this context, the hypothesis of the study is that the innovation performance of countries is related to the dimensions of sustainable development. This assumption will be empirically tested in the following section.

\section{DATA AND METHODOLOGY}

The dataset of the study consists of 35 OECD member countries and the statistics of these countries between 2007-2019 years. In the balanced panel data created, four basic variables were handled. The OECD countries and variable set discussed in the study are presented in the tables below.

Table 1: Countries Included in the Study

\begin{tabular}{llllllll}
\hline Country & Code & Country & Code & Country & Code & Country & Code \\
\hline USA & 1 & France & 10 & Italy & 19 & Poland & 28 \\
\hline Germany & 2 & South Korea & 11 & Iceland & 20 & Portugal & 29 \\
\hline Australia & 3 & Netherlands & 12 & Japan & 21 & Slovakia & 30 \\
\hline Austria & 4 & United Kingdom & 13 & Canada & 22 & Slovenia & 31 \\
\hline Belgium & 5 & Ireland & 14 & Latvia & 23 & Chile & 32 \\
\hline Czech Republic & 6 & Spain & 15 & Luxembourg & 24 & Turkey & 33 \\
\hline Denmark & 7 & Israel & 16 & Hungary & 25 & New Zealand & 34 \\
\hline Estonia & 8 & Sweden & 17 & Mexican & 26 & Greece & 35 \\
\hline Finland & 9 & Switzerland & 18 & Norway & 27 & &
\end{tabular}


Table 2: Variables Description and Data Sources

\begin{tabular}{|c|c|c|c|c|}
\hline Variables & Description & Measurement & Period & Source \\
\hline INNOV & $\begin{array}{l}\text { Global Innovation Index } \\
\text { (GII) score }\end{array}$ & $\begin{array}{l}\text { It is measured with values } \\
\text { between } 0-100 .\end{array}$ & 2007-2019 & Global Innovation Index \\
\hline $\mathrm{CO}_{2}$ & $\mathrm{CO}_{2}$ emission per capita & Metric tons / person & 2007-2019 & $\begin{array}{l}\text { World Bank, International Energy } \\
\text { Agency, World Population Review (WPR) }\end{array}$ \\
\hline GDP & per capita GDP & $\begin{array}{l}\text { Constant } 2010 \text { US\$ / } \\
\text { person }\end{array}$ & 2007-2019 & World Bank, Statista \\
\hline $\mathrm{HDI}$ & $\begin{array}{l}\text { Human Development } \\
\text { Index (HDI) score }\end{array}$ & $\begin{array}{l}\text { It is measured with values } \\
\text { between } 0-1 .\end{array}$ & 2007-2019 & $\begin{array}{l}\text { United Nations Development Program, } \\
\text { World Population Review (WPR) }\end{array}$ \\
\hline
\end{tabular}

Throughout the study, separate regression models were established for each variable. The estimated panel data models in this study are summarized below.

$\operatorname{InINNO}_{i t}=\alpha_{i t}+\beta_{1} \operatorname{InGDP}_{i t}+\beta_{2} \operatorname{InCO}_{i t}+\beta_{3} \operatorname{InHDI} I_{i t}+u_{i t}$ $\operatorname{InGDP}_{i t}=\alpha_{i t}+\beta_{1} \operatorname{InINNO}_{i t}+\beta_{2} \operatorname{InCO}_{i t}+\beta_{3} \operatorname{InHDI}_{i t}+u_{i t}$ $\operatorname{InCO2}_{i t}=\alpha_{i t}+\beta_{1} \operatorname{InINNO}_{i t}+\beta_{2} \operatorname{InGDP}_{i t}+\beta_{3} \operatorname{InHDI}_{i t}+u_{i t}$ $\operatorname{InHDI}_{i t}=\alpha_{i t}+\beta_{1} \operatorname{InINNO}_{i t}+\beta_{2} \operatorname{InGDP}_{i t}+\beta_{3} \operatorname{InCO}_{i t}+u_{i t}$

Some preliminary tests are required for variables before proceeding with the analysis. First, cross-sectional dependence will be investigated. Pesaran's (2004) $C D$ test calculates the presence of possible correlations between units by the following formula (Pesaran, 2004).

$$
C D=\sqrt{\frac{2 T}{N(N-1)}}\left(\sum_{i=1}^{N-1} \sum_{j=i+1}^{N} p_{i j}\right)
$$

The null hypothesis of this test is the non-existence of cross-sectional dependence. In the panel unit root test context, two generations of tests have been developed: a first-generation (Levin, Lin and Chu (2002); Im, Pesaran, Shin (2003); Breitung, (2000); and Hadri, (2000)) whose main limit is the assumption of cross-sectional independence across units; a second-generation Multivariate Augmented Dickey-Fuller (MADF), Seemingly Unrelated Regression Augmented Dickey-Fuller (SURADF) and Pesaran CIPS 2007 (Cross-sectionally Augmented IPS) of tests that rejects the cross-sectional independence hypothesis. In this study, the Pesaran CIPS test, one of the second-generation unit root tests, will be used since there is a correlation between cross-section units. In this test, Cross-sectional Augmented Dickey-Fuller (CADF) values are calculated for each variable in the model. Then, the CIPS statistical value of each variable is calculated by taking the arithmetic average of the CADF values. CIPS test statistics are calculated with the help of the formula presented below (Pesaran, 2007).

$$
C I P S=C A D F=\frac{1}{N} \sum_{i}^{N} C A D F_{i}
$$

Then, the panel cointegration test developed by Pedroni (1999) will be used to determine whether there is a stable long-term relationship among the variables. Pedroni (1999) proposed seven basic statistics to test the cointegration relationship in heterogeneous panels. With the help of these basic statistics, the long-term relationship between the variables will be tested. After the cointegration test, the coefficient estimates of the variables interacting in the long term will be determined by using FMOLS and DOLS techniques (Phillips \& Hansen, 1990). The formula of FMOLS is given below:

$\beta^{\lambda}=N^{-1} \sum_{i=1}^{N}\left(\sum_{t=1}^{T}\left(y_{i t}-\bar{y}\right)^{2}\right)^{-1}\left(\sum_{t=1}^{T}\left(y_{i t}-\bar{y}\right)\right) z_{i t}^{*}-T_{n i}$

The formula of DOLS is given below (Saikkonen, 1991):

$$
\beta=\frac{1}{N} \sum_{i=1}^{N}\left[\left(\sum_{t=1}^{T}\left(Z_{i, t} Z_{i, t}\right)\right)^{-1}\left(\sum_{t=1}^{T} Z_{i, t} W_{i, t}\right)\right]
$$

Finally, the Vector Error Correction Model (VECM) will be used to identify short-term relationships between variables. It is a test that produces effective results for both the short term and the long term, the causality relationship between the variables was examined with the help of Granger causality tests developed by Dumitrescu and Hurlin (2012).

All analyses will be made by using Eviews and STATA software packages.

\section{FINDINGS}

Descriptive statistics and correlation matrix for the four basic variables used in the analysis are presented below. 
Table 3: Descriptive Statistics

\begin{tabular}{|c|c|c|c|c|c|c|c|c|}
\hline & INNO & & $\mathrm{CO}_{2}$ & & GDP & & HDI & \\
\hline Country & Mean & SD & Mean & SD & Mean & SD & Mean & SD \\
\hline USA & 43,08 & 26,30 & 16,44 & 1,40 & 51739,03 & 4499,96 & 0,91 & 0,01 \\
\hline Germany & 40,90 & 25,07 & 9,03 & 0,36 & 44185,74 & 2347,95 & 0,93 & 0,01 \\
\hline Australia & 37,60 & 23,27 & 16,64 & 1,13 & 53791,17 & 1851,34 & 0,93 & 0,01 \\
\hline Austria & 37,53 & 23,16 & 7,53 & 0,48 & 48133,22 & 1096,52 & 0,90 & 0,01 \\
\hline Belgium & 36,75 & 22,63 & 8,76 & 0,77 & 45006,27 & 1077,15 & 0,91 & 0,01 \\
\hline Czech Republic & 35,35 & 22,10 & 10,01 & 0,84 & 20976,62 & 1384,83 & 0,87 & 0,01 \\
\hline Denmark & 41,72 & 25,83 & 6,82 & 1,35 & 60070,83 & 1944,81 & 0,92 & 0,01 \\
\hline Estonia & 36,68 & 23,02 & 12,88 & 1,48 & 17559,74 & 2361,02 & 0,86 & 0,02 \\
\hline Finland & 42,68 & 26,58 & 9,27 & 1,53 & 47220,34 & 1504,49 & 0,91 & 0,01 \\
\hline France & 37,98 & 23,41 & 4,96 & 0,50 & 41640,83 & 916,87 & 0,88 & 0,01 \\
\hline South Korea & 39,83 & 24,66 & 11,33 & 0,63 & 24090,86 & 3130,49 & 0,89 & 0,01 \\
\hline Netherlands & 43,42 & 27,09 & 9,89 & 0,85 & 51992,15 & 1354,39 & 0,92 & 0,01 \\
\hline United Kingdom & 43,56 & 27,00 & 6,85 & 1,11 & 41120,08 & 1356,73 & 0,91 & 0,01 \\
\hline Ireland & 41,04 & 25,64 & 8,05 & 0,98 & 58511,03 & 11534,91 & 0,91 & 0,02 \\
\hline Spain & 34,47 & 21,41 & 5,78 & 0,87 & 30796,63 & 1304,51 & 0,88 & 0,01 \\
\hline Israel & 39,35 & 24,54 & 8,20 & 0,91 & 32867,14 & 3440,90 & 0,89 & 0,01 \\
\hline Sweden & 45,04 & 28,07 & 4,52 & 0,76 & 54129,46 & 2331,42 & 0,92 & 0,02 \\
\hline Switzerland & 47,67 & 29,91 & 4,70 & 0,41 & 76527,07 & 2637,57 & 0,93 & 0,01 \\
\hline Italy & 32,78 & 20,35 & 6,14 & 0,94 & 35244,64 & 1534,53 & 0,87 & 0,01 \\
\hline Iceland & 39,23 & 24,30 & 6,18 & 0,48 & 47673,63 & 3944,53 & 0,91 & 0,02 \\
\hline Japan & 38,29 & 23,44 & 9,23 & 0,39 & 45645,14 & 2224,74 & 0,90 & 0,01 \\
\hline Canada & 39,68 & 24,47 & 15,58 & 0,67 & 49022,38 & 1644,46 & 0,91 & 0,01 \\
\hline Latvia & 31,53 & 19,84 & 3,57 & 0,15 & 13973,48 & 1957,33 & 0,83 & 0,01 \\
\hline Luxembourg & 40,09 & 24,95 & 18,38 & 3,29 & 107333,99 & 3614,20 & 0,90 & 0,01 \\
\hline Hungary & 32,16 & 20,11 & 4,73 & 0,42 & 14442,24 & 1396,77 & 0,83 & 0,01 \\
\hline Mexican & 25,23 & 15,54 & 3,99 & 0,32 & 9784,33 & 422,84 & 0,75 & 0,01 \\
\hline Norway & 38,51 & 23,81 & 9,15 & 2,13 & 88750,86 & 3589,98 & 0,95 & 0,01 \\
\hline Poland & 28,97 & 18,03 & 7,90 & 0,35 & 13799,51 & 1605,67 & 0,85 & 0,02 \\
\hline Portugal & 32,41 & 20,19 & 4,71 & 0,42 & 22426,52 & 804,52 & 0,83 & 0,01 \\
\hline Slovakia & 30,09 & 18,55 & 6,15 & 0,49 & 18021,53 & 1593,99 & 0,84 & 0,01 \\
\hline Slovenia & 33,52 & 20,91 & 7,03 & 0,74 & 24387,62 & 1361,47 & 0,89 & 0,01 \\
\hline Chile & 28,37 & 17,43 & 4,51 & 0,24 & 13933,14 & 1131,87 & 0,83 & 0,02 \\
\hline Turkey & 26,52 & 16,35 & 4,27 & 0,24 & 12195,91 & 1962,84 & 0,77 & 0,04 \\
\hline New Zealand & 38,40 & 23,96 & 7,18 & 0,64 & 36011,40 & 2370,95 & 0,91 & 0,01 \\
\hline Greece & 27,31 & 16,90 & 6,88 & 1,17 & 24613,01 & 3141,93 & 0,86 & 0,01 \\
\hline
\end{tabular}

Note: SD indicates Standard Deviation.

Table 4: Pearson Correlations

\begin{tabular}{lllll}
\hline & INNO & GDP & $\mathrm{CO}_{2}$ & $\mathrm{HDI}$ \\
\hline INNO & 1,000 & & & \\
\hline $\mathrm{GDP}$ & $0,2075^{*}$ & 1,000 & & \\
\hline $\mathrm{CO}_{2}$ & $-0,052$ & $0,442^{*}$ & 1,000 & \\
\hline $\mathrm{HDI}$ & $0,395^{*}$ & $0,727^{*}$ & $0,376^{*}$ & 1,000 \\
\hline
\end{tabular}

A correlation was found between the series, and stationarity analysis of the series was initiated using the second-generation unit root tests.

${ }^{*}$ significance at the level of 0.05 
Table 5: Panel Unit Root Tests

\begin{tabular}{llll}
\hline Variables & $\begin{array}{l}\text { Pesaran CD } \\
(2004)\end{array}$ & $\begin{array}{l}\text { Pesaran } \\
(2007) \text { CIPS }\end{array}$ & $\begin{array}{l}\text { Pesaran }(2007) \\
\text { CIPS }(\triangle)\end{array}$ \\
\hline INNO & $87,871^{*}(0,000)$ & $-2,577^{*}$ & $-3,968^{*}$ \\
\hline $\mathrm{CO}_{2}$ & $42,531^{*}(0,000)$ & $-1,957$ & $-2,776^{*}$ \\
\hline $\mathrm{GDP}$ & $42,373^{*}(0,000)$ & $-0,847$ & $-2,88^{*}$ \\
\hline $\mathrm{HDI}$ & $81,396^{*}(0,000)$ & $-2,077$ & $-3,968^{*}$ \\
\hline
\end{tabular}

${ }^{*} 0,01$ expresses significance at the level of 0.01 . $\triangle$ expresses the primary difference of the series.

According to the table, when cross-sectional dependence test results are examined, it is concluded that contains there is a correlation of 0.01 significance level in each series in the panel, that is, the countries in cross-sections are not independent of each other. The results reported in Table 5 indicate that all the series considered are non-stationary at their level except innovation. However, all the series are stationary at first difference.

Table 6 reports the results of the panel cointegration tests developed by Pedroni (2004). Pedroni used seven basic statistics (four within-dimension and three between-dimension) to reveal the cointegration relationship in heterogeneous panels.

According to the results of the within-dimensions tests and the between-dimensions tests indicates that the null hypothesis of no cointegration is rejected. When the probability values within-dimensions are examined, it is observed that Panel PP and Panel ADF statistics are significant at the level of 0.01 . Besides, when the results of the between-dimensions are analyzed, it is seen that the Group PP and Group ADF statistics are significant at the level of 0.01 . This situation proves the existence of a long-term co-integration relationship between the relevant variables. In other words, it was determined that the variables of Innovation, GDP, $\mathrm{CO}_{2}$ and, $\mathrm{HDI}$ are in a long-term relationship based on the countries discussed.

Table 6: Pedroni Cointegration Results

\begin{tabular}{|c|c|c|c|}
\hline & & t- Statistics & Probability \\
\hline \multirow{4}{*}{$\begin{array}{l}\text { Within- } \\
\text { dimension }\end{array}$} & Panel v-stat & 0,931 & 0,9393 \\
\hline & Panel rho-stat & 1,269 & 0,9103 \\
\hline & Panel PP-stat & $-8,413$ & $0,0000^{*}$ \\
\hline & Panel ADF-stat & $-4,598$ & $0,0000^{*}$ \\
\hline \multirow{3}{*}{$\begin{array}{l}\text { Between- } \\
\text { dimension }\end{array}$} & Group rho-stat & 4,112 & 1,000 \\
\hline & Group PP-stat & $-12,566$ & $0,000^{*}$ \\
\hline & Group ADF-stat & $-5,720$ & $0,000^{*}$ \\
\hline
\end{tabular}

${ }^{*} 0,01$ expresses significance at the level of 0.01 . HO: There is no cointegration in the series.

The existence of a long-term relationship found as a result of the cointegration test was estimated by established regression models. FMOLS and DOLS estimators were used to estimate the regression coefficients.

Table 7: FMOLS and DOLS Results

\begin{tabular}{|c|c|c|c|c|}
\hline Panel & INNO & $\mathrm{CO}_{2}$ & GDP & $\mathrm{HDI}$ \\
\hline \multicolumn{5}{|c|}{$I N N O=f\left(C O_{2^{\prime}} G D P, H D I\right)$} \\
\hline FMOLS & - & $-2,829 *(0,000)$ & $1,365^{*}(0,000)$ & $4,664^{*}(0,000)$ \\
\hline DOLS & - & $-2,674^{*}(0,001)$ & $1,374^{*}(0,000)$ & $5,518^{*}(0,000)$ \\
\hline \multicolumn{5}{|c|}{$C O 2=f(I N N O, G D P, H D I)$} \\
\hline FMOLS & $-0,007^{*}(0,001)$ & - & $0,125^{*}(0,000)$ & $-7,240^{*}(0,000)$ \\
\hline DOLS & $-0,008^{*}(0,025)$ & - & $0,126^{*}(0,000)$ & $-6,990 *(0,000)$ \\
\hline \multicolumn{5}{|c|}{$G D P=f\left(I N N O, C O_{2^{\prime}} H D I\right)$} \\
\hline FMOLS & $0,306^{*}(0,000)$ & $4,563^{*}(0,000)$ & - & $-2,489(0,514)$ \\
\hline DOLS & $0,298 *(0,000)$ & $4,384^{*}(0,000)$ & - & $-5,810(0,256)$ \\
\hline \multicolumn{5}{|c|}{$H D I=f\left(I N N O, C O_{z^{\prime}} G D P\right)$} \\
\hline FMOLS & $0,005^{*}(0,000)$ & $-0,076^{*}(0,000)$ & $0,000(0,656)$ & - \\
\hline DOLS & $0,005^{*}(0,000)$ & $-0,070^{*}(0,000)$ & $-0,000(0,806)$ & - \\
\hline
\end{tabular}

** It expresses significance at the level of 0.05 . Values in parentheses represent probability values. In the DOLS model, the lag length is selected automatically. No trend and grouped method was preferred in FMOLS technique. 
According to Table 7 for the first equation, the coefficients of $\mathrm{CO}_{2}$ are $-2,829$ for the FMOLS estimator and $-2,674$ for the DOLS estimator. Accordingly, $\mathrm{CO}_{2}$ has a negative and statistically significant effect on innovation performance at $5 \%$ level. The coefficients of GDP are 1,365 for the FMOLS estimator and 1,374. GDP has a positive and significant effect on innovation performance at $5 \%$ level. Similarly, the coefficients of HDI are 4,664 for the FMOLS estimator and 5,518 for the DOLS estimator. HDI has a positive and significant effect on innovation performance at $5 \%$ level.

For the second equation, the coefficients of innovation are $-0,007$ for the FMOLS estimator and $-0,008$ for the DOLS estimator. It can be seen that innovation performance has a negative and statistically significant effect on $\mathrm{CO}_{2}$ at $5 \%$ level. The coefficients of GDP are 0,125 for the FMOLS estimator and 0,126 for the DOLS estimator. GDP has a positive and statistically significant effect on $\mathrm{CO}_{2}$. On the other hand, the coefficients of $\mathrm{HDI}$ are $-7,240$ for the FMOLS estimator and $-6,990$ for the DOLS estimator. HDI has a negative and statistically significant impact on $\mathrm{CO}_{2}$.

When the third equation is examined, it is observed that the coefficient is 0,306 for the FMOLS estimator and the coefficient is 0,298 for the DOLS estimator for innovation performance. Innovation performance has a positive and statistically significant impact on GDP per capita. Coefficients of $\mathrm{CO}_{2}$ emissions are 4,563 and 4,384, respectively. The effect of $\mathrm{CO}_{2}$ on economic growth is positive and statistically significant. Coefficients of HDI are $-2,489$ and $-5,810$, respectively. The HDI variable was found to have a positive and statistically insignificant impact on GDP per capita.

Finally, in the fourth equation coefficients of innovation performance is 0,005 for the FMOLS estimator and the DOLS estimator. Innovation performance has a positive and statistically significant impact on HDI. Coefficients of $\mathrm{CO}_{2}$ emissions are $-0,076$ and $-0,070$, respectively. $\mathrm{CO}_{2}$ has a negative and statistically significant effect on $\mathrm{HDI}$. Finally, the GDP variable was found to have a positive and statistically insignificant impact on HDI for the FMOLS estimator. Also, it has a negative and statistically insignificant impact on HDI for the DOLS estimator.

Vector Error Correction Model (VECM) was used to reveal the long-run causality relationship between the variables. As a result of the model, the causality relationships between the variables were defined with the help of the Granger causality test. The long and short-run causality relationships formed as a result of VECM are presented in the table.

Table 8: Panel Granger Causality and VECM

\begin{tabular}{cccccc}
\hline Dependent Variables & \multicolumn{3}{c}{ Independent Variables (Short-run) } & \multicolumn{1}{c}{ Long-run } \\
\cline { 2 - 6 } & $\Delta I N N O$ & $\Delta C_{2}$ & $\Delta G D P$ & $\Delta H D I$ & $E C T$ \\
\hline$\Delta \mathrm{NNNO}$ & - & $3,582^{*}(0,000)$ & $9,320^{*}(0,000)$ & $4,060(0,415)$ & $-0,491^{*}(0,000)$ \\
\hline$\Delta \mathrm{CO}_{2}$ & $4,521(0,962)$ & - & $1,062(0,287)$ & $2,682^{*}(0,007)$ & $-0,913^{*}(0,001)$ \\
\hline$\Delta \mathrm{GDP}$ & $-0,679(0,496)$ & $3,522^{*}(0,000)$ & - & $11,957^{*}(0,000)$ & $-0,002(0,108)$ \\
\hline$\Delta \mathrm{HDI}$ & $4,358(0,542)$ & $1,859^{*}(0,063)$ & $2,811^{*}(0,004)$ & - & $0,002^{*}(0,0023)$ \\
\hline
\end{tabular}

Short-run causality was analyzed by Dumitrescu \& Hurlin (2012) causality test. Relevant values are Zbar statistical values. Values in parentheses are probability values. ${ }^{*}$ Expresses significance at the level of 0.05 . ECT: Error Correction Term was calculated for the long run with the help of $t$ test.

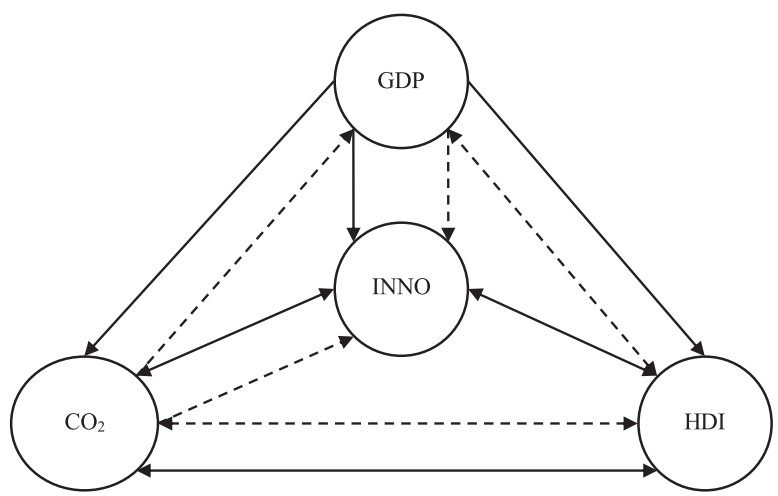

Figure 2: Short and Long-run Causalities between Variables Note: The dashed lines indicate short-run, straight lines indicate longrun relationships
For the short-run causality test, Fig. 2 shows that results confirm the unidirectional causality running from GDP per capita and $\mathrm{CO}_{2}$ to innovation performance. Besides, it was found that there is a bidirectional causal relationship between $\mathrm{CO}_{2}$ and $\mathrm{HDI}$. Also, there is a unidirectional causality running from $\mathrm{CO}_{2}$ to GDP. Bidirectional causality between $\mathrm{HDI}$ and GDP has also been identified.

For the long-run causality test, there is bidirectional causality between HDI and innovation performance. Also, there is a unidirectional causality running from GDP per capita to innovation performance, $\mathrm{CO}_{2}$ and $\mathrm{HDI}$. Bidirectional causality between $\mathrm{CO}_{2}$ and $\mathrm{HDI}$ has 
also been identified. Similarly, it was found that there is a bidirectional causal relationship between $\mathrm{CO}_{2}$ and innovation performance.

\section{DISCUSSION}

Today, global problems and their solutions are an issue that all countries emphasize, and it is also one of the important topics on the agenda of national and international organizations. The concept of sustainable development, which stands out in this context, has replaced the traditional development model and has become the priority of all countries. Many factors affect sustainable development. Innovation, which is at the center of the traditional development model, is an integral part of sustainable development.

Innovation is seen as a key driver of competitiveness and economic growth (Porter \& Stern, 2002) Many OECD member countries have implemented strategies and policies to increase their innovation performance and economic progress. The results suggest a positive relationship between per capita GDP and innovation performance. This result confirms the findings of (Ülkü, 2004). Also, in the 2018 report of The Global Innovation Index, it is stated that all editions of the GIl demonstrate the positive relationship between innovative performance and GDP per capita (Dutta et al., 2018). It is not surprising that the results are the same in this study, which also includes 2019 data.

According to relevant literature, innovation activities contribute to economic growth. It is found that there is unidirectional causality from economic growth to innovation performance. A similar conclusion was reached by Maradana et al. (2017). They found both bidirectional and unidirectional causality between innovation and per capita GDP over the period 1989-2014 for 19 European countries. Similarly, Avila-Lopez, Lyu, \& Lopez-Leyva (2019) found unidirectional causality from per capita economic growth to innovation in Brazil.

It was found that innovation has a negative and statistically significant impact on $\mathrm{CO}_{2}$ emissions. But the magnitude of coefficients $(-0,007$ and $-0,008)$ implies that a $1 \%$ increase in innovation performance decreases $\mathrm{CO}_{2}$ emissions by around $0,007 \%$. This result is in line with the research of Mensah et al., (2018) showing that innovation plays a vital role in decreasing $\mathrm{CO}_{2}$ emissions in the sample of OECD countries. A similar result was obtained in another study addressing different regions. Dauda, Long, Mensah, \& Salman (2019) found that innovation reduces $\mathrm{CO}_{2}$ emissions in $\mathrm{G} 6$ countries. However, according to their results, it increases $\mathrm{CO}_{2}$ emissions in the BRICS and the MENA countries. Furthermore, Long, Luo, Wu, \& Zhang, (2018) found that innovation has a negative impact on $\mathrm{CO}_{2}$ emission intensity in China.

The findings indicate the presence of unidirectional causality running from $\mathrm{CO}_{2}$ to innovation performance in the short run. However, in the long run, a bidirectional causal relationship between the variables. This result is consistent with the findings of Fan \& Hossain (2018) which claimed that there is a bidirectional causality is running between $\mathrm{CO}_{2}$ emissions and technological innovation.

The results suggest a positive relationship between innovation performance and human development. This result is in line with the finding of Ejemeyovwi, Osabuohien, Johnson (2019) which found that innovation has a significant and positive relationship with human development in Africa. However, this result contradicts the findings of Silva \& Moreira (2019) which not confirmed the relationship between innovation and human development.

According to the results, it is also found that there is a positive relationship between GDP and $\mathrm{CO}_{2}$ emissions. This result confirms the finding of Çınar (2011) which indicated an increase in GDP increases $\mathrm{CO}_{2}$ emissions in the long run in OECD countries. This finding contradicts the findings of Acheampong (2018) which viewed a regional variation in the causal relationship between GDP-carbon emissions.

Furthermore, there is a negative relationship between $\mathrm{HDI}$ and $\mathrm{CO}_{2}$ emissions. This result is in line with the findings of Ouedraogo (2013) which found a negative cointegration relationship between energy consumption and the HDI. However this result contradicts the findings of Costa, Rybski, \& Kropp (2011) which found a positive and time-dependent correlation between the $\mathrm{HDI}$ and per capita $\mathrm{CO} 2$ emissions from fossil fuel combustion.

\section{CONCLUSION}

The concept of innovation has been existed for a long time and has been seen as a tool for all businesses and even countries to achieve economic development. Innovation policy has started to be an item in the national policies of many developed and developing 
countries with the influence of international institutions such as OECD. Many countries have developed national strategies to support innovation activities. It has been assumed that economic development will eventually provide welfare for those living in that country. However, it has been seen over the years that the real welfare for countries is not only achieved with economic development. At this point, the concept of sustainable development, which includes social and environmental progress as well as economic development, has been emerged.

In the 2030 Agenda for Sustainable Development, innovation is one of the SDGs (Goal 9) and also a means for achieving the others. Today, innovation has the mission of serving sustainable development as well as increasing national income. In this study, it was investigated whether this mission was realized or not. According to the results of the analysis, innovation has a positive effect on sustainable development. Therefore it can be argued that innovation is more than just a tool for economic progress. It would be more appropriate to see innovation as a comprehensive tool that also serves the economic, social, and environmental dimensions of development.

\section{MANAGERIAL IMPLICATIONS}

This study contributes to the existing literature in several ways. The most important result obtained in the study is that innovation performance contributes to every pillar of sustainable development. This means that every country which has a sustainable development goal must have activities that will improve its innovation performance. The determination of short and long-run relationships between innovation performance and other variables is another contribution to the literature. In this way, it is expected that the study will guide countries' development strategies and policies by helping them to understand what to focus on.

\section{LIMITATIONS}

The study has some limitations. First, only accessible data were used to measure the dimensions of sustainable development. Undoubtedly, sustainable development is a comprehensive concept that can be expressed with many more variables than these. Second, countries with available data on variables are included in the study. Future research should include more countries to the analysis as the number of countries' relevant data increases. This will make it possible for future studies to yield more accurate results. 


\section{References}

Acheampong, A. O. (2018). Economic Growth, $\mathrm{CO}_{2}$ Emissions and Energy Consumption: What Causes What and Where? Energy Economics, 74, 677-692.

Avila-Lopez, L. A., Lyu, C., \& Lopez-Leyva, S. (2019). Innovation and Growth: Evidence from Latin American Countries. Journal of Applied Economics, 22(1), 287-303.

Batie, S. S., Sedjo, R. A., \& Fedkiw, J. (2008). Sustainability: From Natural Resource Sufficiency to Ecosystem Functional Integrity. R. A. Sedjo inside, Perspectives on Sustainable Resources in America (s. 11-21). Washington: RFF Press Book.

Breitung, J. (2000). The Local Power of Some Unit Root Tests for Panel Data. Nonstationary Panels, Panel Cointegration and Dynamic Panels, 15,161-177.

Constantinescu, A., \& Frone, S. (2014). The Role of Technological Innovation in Sustainable Economic Development. Journal of Knowledge Management, Economics and Information Technology, 4(1.1),1-13.

Costa, L., Rybski, D., \& Kropp, J. P. (2011). A Human Development Framework for $\mathrm{CO}_{2}$ Reductions. PLoSONE, 6(12), 1-9.

Çınar, S. (2011). Income and CO2 Emissions: Panel Unit Root and Cointegration Tests. Uludağ Journal of Economy and Society, 30(2),71-83.

Dauda, L., Long, X., Mensah, C. N., \& Salman, M. (2019). The Effects of Economic Growth and Innovation on $\mathrm{CO}_{2}$ Emissions. Environmental Science and Pollution Research, 26(15),15028-15038.

Dumitrescu, E.-I., \& Hurlin, C. (2012). Testing for Granger Non-causality in Heterogeneous Panels. Economic Modelling, 29(4), 1450-1460.

Dutta, S., Reynoso, R. E., Garanasvili, A., Saxena, K., Lanvin, B., Wunsch-Vincent, S., .. Guadagno, F. (2018). The Global Innovation Index 2018: Energizing the World with Innovation. S. Dutta, B. Lanvin, \& S. Wunsch-Vincent inside, Global Innovation Indeks 2018 (s. 3-54). Retrieved from https:// www.wipo.int/edocs/pubdocs/en/wipo_pub_gii_2018.pdf.

Ejemeyovwi, J. O., Osabuohien, E. S., Johnson, O. D., \& Bowale, E. I. (2019). Internet Usage, Innovation and Human Development Nexus in Africa: The Case of ECOWAS. Journal of Economic Structures, 8(1),1-16.

Fan, H., \& Hossain, M. I. (2018). Technological Innovation, Trade Openness, $\mathrm{CO}_{2}$ Emission and Economic Growth: Comparative Analysis between China and India. International Journal of Energy Economics and Policy, 8(6),240-257.

Garren, S. J., \& Brinkmann, R. (2018). Sustainability Definitions, Historical Context, and Frameworks. R. Brinkmann, \& S. J. Garren inside, The Palgrave Handbook of Sustainability Case Studies and Practical Solutions (s. 1-18). Cham: Palgrave Macmillan.
Giovannini, E., Niestroy, I., Nilsson, M., Roure, F., \& Spanos, M. (2015). The Role of Science, Technology and Innovation Policies to Foster the Implementation of the Sustainable Development Goals Report of the Expert Group "Follow-up to Rio+20, notably the SDGs". Luxembourg: European Commission.

Hadri, K. (2000). Testing for Stationarity in Heterogeneous Panel Data. The Econometrics Journal, 3(2),48-161.

Hauff, M. v., \& Jörg, A. (2010). Innovation and Sustainable Development: From Mainstream Innovation Theory to Sustainable Innovation Research. F. Teuteberg, \& J. M. Gomez içinde, Corporate Environmental Management Information Systems: Advancements and Trends (s. 37-54). Hershey: IGI Global.

Im, K. S., Pesaran, M., \& Shin, Y. (2003). Testing for Unit Roots in Heterogeneous Panels. Journal of Econometrics, 115(1),53-74.

Kaswana, V., Choudhary, M., Kumar, P., Kaswan, S., \& Bajyad, P. (2009). Green Production Strategies. Encyclopedia of Food Security and Sustainability, 1, 492-500.

Levin, A., Lin, C.-F., \& Chu, C.-S. J. (2002). Unit Root Tests in Panel Data: Asymptotic and Finite-sample Properties. Journal of Econometrics, 108(1),1-24.

Long, X., Luo, Y., Wu, C., \& Zhang, J. (2018). The Influencing Factors of $\mathrm{CO}_{2}$ Emission Intensity of Chinese Agriculture from 1997 to 2014. Environmental Science and Pollution Research, 25,13093-13101.

Maradana, R. P., Pradhan, R. P., Dash, S., Gaurav, K., Jayakumar, M., \& Chatterjee, D. (2017). Does Innovation Promote Economic Growth? Evidence from European Countries. Journal of Innovation and Entrepreneurship, 6(1),1-23.

Mensah, C. N., Long, X., Boamah, K. B., Bediako, I. A., Dauda, L., \& Salman, M. (2018). The Effect of Innovation on $\mathrm{CO}_{2}$ Emissions of OECD Countries from 1990 to 2014. Environmental Science and Pollution Research, 25(1), 29678-29698.

Mulder, K. F. (2007). Innovation for Sustainable Development: From Environmental Design to Transition Management. Sustainability Science, 2(2),253-263.

Munier, N. (2005). Introduction to Sustainability Road to a Better Future. Dordrecht: Springer.

Ouedraogo, N. S. (2013). Energy Consumption and Human Development: Evidence from A Panel Cointegration and Error Correction Model. Energy, 63, 28-41.

Pedroni, P. (1999). Critical Values for Cointegration Tests in Heterogeneous Panels with Multiple Regressors. Oxford Bulletin Of Economics and Statistics, Special Issue, 61(S1), 653-670.

Pesaran, H. M. (2004). General Diagnostic Tests for Cross Section Dependence in Panels. Cambridge Working Papers in Economics Working Paper, Discussion Paper No. 1240. 
Pesaran, M. H. (2007). A Simple Panel Unit Root Test in the Presence of Cross-section Dependence. Journal of Applied Econometrics, 22(2), 265-312.

Phillips, P. C., \& Hansen, B. E. (1990). Statistical Inference in Instrumental Variables Regression with I(1) Processes. The Review of Economic Studies, 57(1),99-125.

Porter, M. E., \& Stern, S. (2002). National Innovative Capacity. M. E. Porter, J. D. Sachs, P. K. Cornelius, J. W. McArthur, \& K. Schwab inside, The Global Competitiveness Report 2001-2002 (s. 102-119). New York: Oxford University Press.

Praetorius, B., Bauknecht, D., Cames, M., Fischer, C., Pehnt, M., Schumacher, K., \&Voß, J.-P. (2009). Innovation for Sustainable Electricity Systems. Heidelberg: Physica-Verlag.

Purvis, B., Mao, Y., \& Robinson, D. (2019). Three Pillars of Sustainability: In Search of Conceptual Origins. Sustainability Science, 14(3),681-695.

Saikkonen, P. (1991). Asymptotically Efficient Estimation of Cointegration Regressions. Econometric Theory, 7(1),1-21.

Santana, N. B., Rebelatto, D. A., Périco, A. E., Moralles, H. F., \& Filho, W. L. (2015). Technological Innovation for Sustainable Development: An Analysis of Different Types of Impacts for Countries in the BRICS and G7 Groups. International Journal of Sustainable Development \& World Ecology, 22(5), 425-436.

Silva, P., \& Moreira, A. C. (2019). The Relationship Between Culture and Human Development: An Analysis Through the Lens of Innovation and Corruption. Z. Nedelko, \& M. Brzozowski inside, Recent Advances in the Roles of Cultural and Personal Values in Organizational Behavior (s. 187-212). Hershey: IGI Global.
Silvestre, B. S., \& Tî̂rcă, D. M. (2019). Innovations for Sustainable Development: Moving Toward a Sustainable Future. Journal of Cleaner Production, 208, 325-332.

Smedt, P.D. (2006). Asking The Right Questions: New Approaches On Measuring Sustainable Development. Economic Commission for Europe Conference of European Statisticians (s. 1-12). Oslo: UNECE/OECD/Eurostat Working Group on Statistics for Sustainable Development.

UNCTAD. (2017). New Innovation Approaches to Support the Implementation of the Sustainable Development Goals. The United Nations Conference on Trade and Development. Retrieved from https://unctad.org/en/PublicationsLibrary/ dtlstict2017d4_en.pdf.

Ülkü, H. (2004). R\&D, Innovation, and Economic Growth: An Empirical Analysis. IMF Working Paper, WP/04/185,1-36.

Waas, T., Hugé, J., Verbruggen, A., \& Wright, T. (2011). Sustainable Development: A Bird's Eye View. Sustainability, 3(10), 1637-1661.

WCED. (1987). Our Common Future. Report of the World Commission on Environment and Development, Retrieved from https://sustainabledevelopment.un.org/content/ documents/5987our-common-future.pdf. 